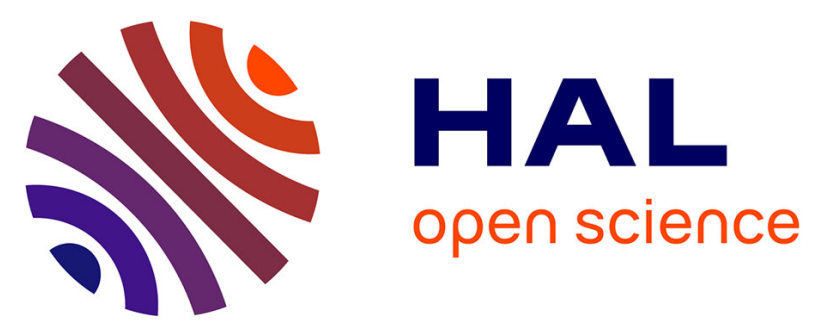

\title{
Arsenic Scavenging by Aluminum-Substituted Ferrihydrites in a Circumneutral pH River Impacted by Acid Mine Drainage
}

Areej Adra, Guillaume Morin, Georges Ona-Nguema, N. Menguy, Fabien Maillot, Corinne Casiot, Odile Bruneel, Sophie Lebrun, Farid Juillot, Jessica Brest

\section{To cite this version:}

Areej Adra, Guillaume Morin, Georges Ona-Nguema, N. Menguy, Fabien Maillot, et al.. Arsenic Scavenging by Aluminum-Substituted Ferrihydrites in a Circumneutral pH River Impacted by Acid Mine Drainage. Environmental Science and Technology, 2013, 47, pp.12784-12792. 10.1021/es4020234 . hal-01018033

\section{HAL Id: hal-01018033 https://hal.science/hal-01018033}

Submitted on 18 Jan 2022

HAL is a multi-disciplinary open access archive for the deposit and dissemination of scientific research documents, whether they are published or not. The documents may come from teaching and research institutions in France or abroad, or from public or private research centers.
L'archive ouverte pluridisciplinaire HAL, est destinée au dépôt et à la diffusion de documents scientifiques de niveau recherche, publiés ou non, émanant des établissements d'enseignement et de recherche français ou étrangers, des laboratoires publics ou privés. 


\title{
Arsenic Scavenging by Aluminum-Substituted Ferrihydrites in a Circumneutral pH River Impacted by Acid Mine Drainage.
}

\author{
Areej Adra, ${ }^{\dagger}$ Guillaume Morin, ${ }^{\dagger, *}$ Georges Ona-Nguema, ${ }^{\dagger}$ Nicolas Menguy, ${ }^{\dagger}$ Fabien Maillot, ${ }^{\dagger, \S}$ \\ Corinne Casiot, ${ }^{\ddagger}$ Odile Bruneel, ${ }^{\ddagger}$ Sophie Lebrun, ${ }^{\dagger}$ Farid Juillot, ${ }^{\dagger}$ and Jessica Brest ${ }^{\dagger}$ \\ ${ }^{\dagger}$ Institut de Minéralogie et de Physique des Milieux Condensés (IMPMC) UMR CNRS 7590, UPMC, UR IRD 206, 4 place Jussieu, \\ 75252 Paris Cedex 05, France \\ ${ }^{\ddagger}$ Laboratoire HydroSciences Montpellier, UMR 5569 CNRS-IRD-UM1\&2, Université Montpellier 2, Place E. Bataillon, CC MSE, \\ 34095 Montpellier cedex 05, France \\ ${ }^{\S}$ Department of Earth and Planetary Sciences, Washington University, St. Louis, Missouri 63130, USA
}

ABSTRACT: Ferrihydrite $(\mathrm{Fh})$ is a nanocrystalline ferric oxyhydroxide involved in the retention of pollutants in natural systems and in water-treatment processes. The status and properties of major chemical impurities in natural $\mathrm{Fh}$ is however still scarcely documented. Here we investigated the structure of aluminum-rich $\mathrm{Fh}$, and their role in arsenic scavenging in river-bed sediments from a circumneutral river ( $\mathrm{pH}$ 6-7) impacted by an arsenic-rich acid mine drainage (AMD). Extended X-ray absorption fine structure (EXAFS) spectroscopy at the $\mathrm{Fe}$ K-edge shows that $\mathrm{Fh}$ is the
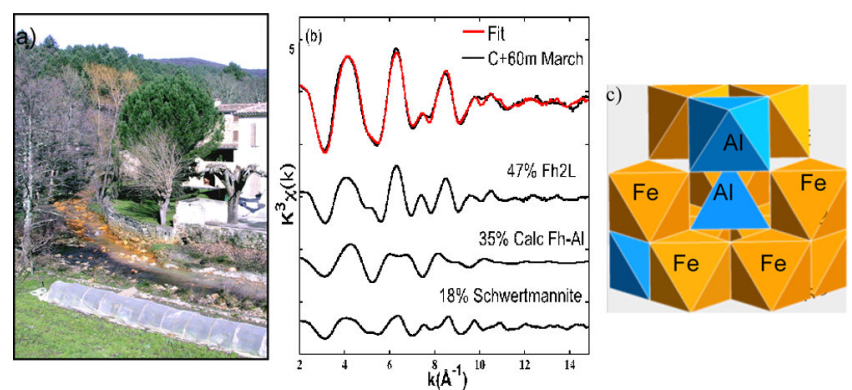
predominant mineral phase forming after neutralization of the AMD, in association with minor amount of schwertmannite transported from the AMD. TEM-EDXS elemental mapping and SEM-EDXS analyses combined with EXAFS analysis indicates that $\mathrm{Al}^{3+}$ substitutes for $\mathrm{Fe}^{3+}$ ions into the Fh structure in the natural sediment samples, with local aluminum concentration within the 25-30 $\pm 10 \mathrm{~mol} \% \mathrm{Al}$ range. Synthetic aluminous Fh prepared in the present study are found to be less Al-substituted (14-20 $\pm 5 \mathrm{~mol} \% \mathrm{Al}$ ). Finally, EXAFS analysis at the arsenic Kedge indicates that $\mathrm{As}(\mathrm{V})$ form similar inner-sphere surface complexes on the natural and synthetic Al-substituted Fh studied. Our results provide direct evidence for the scavenging of arsenic by natural Al-Fh, which emphasize the possible implication of such material for scavenging pollutants in natural or engineered systems.

\section{INTRODUCTION}

Arsenic is a toxic element to humans and other living organisms. It can enter terrestrial and aquatic environments via both natural pathways, such as weathering of rocks and volcanic activity, and anthropic pathways such as industrial and mining activities. ${ }^{1}$ In oxidizing Earth's surface environments, retention of the prevalent inorganic arsenic species is often controlled by adsorption to, or coprecipitation with, iron (oxy)hydroxides such as ferrihydrite. ${ }^{2}$ Ferrihydrite (Fh) is a poorly ordered nanocrystalline $\mathrm{Fe}(\mathrm{III})$-oxyhydroxide with a local structure generally accepted as being related to $\delta$-Keggin cluster geometry containing $20-30 \%$ of tetrahedrally coordinated $\mathrm{Fe}^{3+3-6}$ Because of its large specific surface area $(>200$ $\mathrm{m}^{2} / \mathrm{g}$ ) and high reactivity, ${ }^{7} \mathrm{Fh}$ plays an important role in the sequestration of inorganic pollutants such as arsenic. ${ }^{2,8}$ In soils and surface waters, iron (oxyhydr)oxides are often aluminumsubstituted. The extent of $\mathrm{Al}$ for Fe substitution can reach 33 $\mathrm{mol} \%$ in natural ${ }^{9,10}$ and synthetic ${ }^{11}$ goethite, while it does not exceed $16 \mathrm{~mol} \%$ in synthetic hematite. ${ }^{12,13}$ Aluminum incorporation in ferrihydrite was proposed by Chadwick et al. ${ }^{14}$ on the basis of Mössbauer analysis and the presence of aluminum has been shown to influence the stability of hydrous ferric oxides by retarding their transformation to more crystalline phases. ${ }^{7,14}$ Aluminum was also found to influences the surface properties of hydrous ferric oxides, and their ability to scavenge pollutants such as arsenic. ${ }^{15,16}$ However, the actual structure of the synthetic $\mathrm{Al}: \mathrm{Fe}$ precipitates investigated in these latter laboratory studies was not firmly identified as aluminous ferrihydrite. Recently, $\mathrm{Al}^{3+}$ for $\mathrm{Fe}^{3+}$ substitution in ferrihydrite was demonstrated for synthetic samples by Cismasu et al., ${ }^{17}$ based on pair distribution function analysis of synchrotron X-ray scattering data, transmission electron microscopy, and ${ }^{27} \mathrm{Al}$ nuclear magnetic resonance. Nevertheless, little is known on the occurrence, stability and reactivity of Al$\mathrm{Fh}$ in natural environments. The occurrence of natural $\mathrm{Al}$-rich ferrihydrite has been scarcely reported, ${ }^{18}$ as well as pollutant scavenging by such phases in natural or impacted systems. ${ }^{19}$ 
Hence, better knowledge of the structure of natural Al-bearing ferrihydrite is essential for better evaluating the stability and reactivity of such phase in the environment.

The objectives of the present study were (i) to determine the local structure of naturally Al-bearing ferrihydrites formed in the Amous River downstream of the Carnoulès AMD by extended X-ray absorption fine structure (EXAFS) spectroscopy at the Fe K-edge, (ii) to investigate the mechanism of arsenic uptake by these natural mineral phases using EXAFS spectroscopy at the As K-edge.

\section{MATERIALS AND METHODS}

Field Samples. Arsenic contaminated sediments were sampled in the bed of the Amous River, Gard, France, downstream of its confluence with the acidic Reigous creek, which is heavily contaminated by the Carnoulès AMD (Supporting Information (SI) Figure SI-1). ${ }^{2,20,21}$ In the downstream section of the Reigous Creek and down to its confluence with the pristine Amous River, As(III) and As(V) are scavenged by As-rich schwertmannite, whose crystallinity is strongly affected by arsenate content. ${ }^{21,22}$ The dissolved arsenic concentration in the Reigous Creek at this location ranges between 0.1 and $5 \mathrm{mg} / \mathrm{L}$, depending on the season, ${ }^{20,21}$ and the $\mathrm{pH}$ values range from 3 to 4 (SI Table SI-2). Within the first meters downstream of the confluence between the acid Reigous and the pristine Amous River, the $\mathrm{pH}$ value rises to 6 and the dissolved arsenic concentration decreases below $1.5 \mathrm{mg} / \mathrm{L}$ (SI Table SI-2), which might be attributed to dilution by the Amous River water as well as to sorption onto newly formed Al- and Fe-bearing hydrated gels identified as ferrihydrite in a previous study. ${ }^{20}$ Sediments samples were collected in the Reigous Creek (C-3m) and in the Amous River bed at various distances downstream from the confluence (C) with the Reigous Creek (C+3m, C+20m, C+60m, and C+1200m) (SI Figure SI-1). They mostly consist of fine ocre-brown ferrihydrite-like material in mixture with sand and silt. $^{20}$ Sampling was repeated at two different periods (March 2003 and May 2003) in order to take into account for seasonal variations of the hydrological conditions under Mediterranean climate. After sampling, finely divided material was separated from the sand impurities by wet sieving through a 200 and 50 $\mu \mathrm{m}$ mesh in the Amous water. No color change from the initial ocre-brown color was observed after sampling, sieving and air drying of the sediments, which suggests that the sediments were in oxic conditions. Dry solid samples were stored under dry atmosphere prior to chemical, mineralogical and spectroscopic analyses.

Synthetic Al-Free and Al-Bearing Coprecipitated Ferrihydrite Samples. Al-free 2-Line ferrihydrite sample (Fh2L) was prepared by neutralizing a $0.2 \mathrm{M}$ ferric nitrate solution with $1 \mathrm{M} \mathrm{KOH}$ to a $\mathrm{pH}$ value of $7-8 .^{23}$ Al-bearing Ferrihydrite samples were prepared using a similar protocol but using various $\mathrm{Al} / \mathrm{Fe}$ molar ratios in the starting solutions: 0.30 , $0.51,0.64$, and 0.87 . Starting solutions were prepared by mixing $\mathrm{Fe}\left(\mathrm{NO}_{3}\right)_{3} \cdot 9 \mathrm{H}_{2} \mathrm{O}$ and $\mathrm{Al}\left(\mathrm{NO}_{3}\right)_{3} \cdot 9 \mathrm{H}_{2} \mathrm{O}$ solutions in appropriate ratios with a total $\mathrm{Al}+\mathrm{Fe}$ concentration of $0.2 \mathrm{M}$. Mixed solutions were neutralized to $\mathrm{pH} 7-8$ using $1 \mathrm{M} \mathrm{NaOH}$ under vigorous stirring during $30 \mathrm{~min}$. For the preparation of silicaterich ferrihydrite, $4.04 \mathrm{ge}\left(\mathrm{NO}_{3}\right)_{3} \cdot 9 \mathrm{H}_{2} \mathrm{O}$ were poured into 100 $\mathrm{mL}$ of $0.04 \mathrm{M}$ sodium metasilicate solution $(\mathrm{Si} / \mathrm{Fe}=0.8)$. The solution was then neutralized to $\mathrm{pH} 7.5$ using $1 \mathrm{M} \mathrm{KOH}$ under vigorous stirring. All suspensions were immediately centrifuged after $\mathrm{pH}$ neutralization and the solids were washed twice with
milli-Q water before vacuum drying. The Al-free ferrihydrite sample is referred to as $\mathrm{Fh} 2 \mathrm{~L}$. The $\mathrm{Al}$-ferrihydrite samples are referred to as Fh-Al_0.28, Fh-Al_0.44, Fh-Al_0.64, Fh-Al_0.85, according to their $\overline{\mathrm{A}} \mathrm{l} / \mathrm{Fe}$ molar ratio determined using $\overline{\mathrm{S}} \mathrm{EM}$ EDX analyses. The Si-rich Ferrihydrite is referred to as Fh-Si and is expected to have a solid $\mathrm{Si} / \mathrm{Fe}$ molar ratio of $\sim 0.6$ according to the composition previously reported for a similar HFO-Si sample, that is, $\mathrm{Si} / \mathrm{Fe}=0.75$ molar ratio in solution giving $\mathrm{Si} / \mathrm{Fe}=0.56$ molar ratio in the solid. ${ }^{24}$

Arsenic Sorption Experiments. For comparison with field samples, arsenate sorption experiments were carried out using three of the synthetic ferrihydrite samples described in the previous section (Fh2L, Fh-Al_0.28 and Fh-Al_0.64) at pH value of 6 and at an ionic strength of $0.1 \mathrm{M} \overline{\mathrm{NaCl}}$. Arsenic surface coverage was $1.0 \mu \mathrm{mol} . \mathrm{m}^{-2}$ for all samples with specific surface areas of 233, 209, and $198 \mathrm{~m}^{2} / \mathrm{g}$ for Al-free Fh2L, FhAl_0.28 and Fh-Al_0.64, respectively. (See SI for details on these sorption experiments).

Analytical Methods. Natural and synthetic samples were analyzed for chemical and mineralogical compositions using inductively coupled plasma-atomic emission spectroscopy (ICP-AES), scanning electron microscopy (SEM), and transmission electron microscopy (TEM) coupled with energy dispersive X-ray spectroscopy (EDXS), and using powder X-ray diffraction (XRD). Corresponding analytical procedures are reported in the SI.

EXAFS Data Collection and Analysis. Iron K-edge EXAFS data for the March and May 2003 sediment field samples were recorded at $77 \mathrm{~K}$ in transmission detection mode at the XAFS beamline (ELETTRA, Italy). The Fe K-edge spectrum of the pure Fh2L sample, ${ }^{5}$ and of the synthetic reference schwertmannite sample were recorded at $10 \mathrm{~K}$ in transmission detection mode at the D44 beamline (LURE, France ) and at the SAMBA beamline (SOLEIL, France) for the Fh-Si sample. Fe K-edge EXAFS spectra of the synthetic Alferrihydrite samples were recorded at $10 \mathrm{~K}$ in transmission detection mode at the BM30B-FAME beamline (ESRF, France). Arsenic K-edge EXAFS spectra of the natural samples were recorded at the same beamline at $10 \mathrm{~K}$ in fluorescence detection mode using a 30 elements Ge array detector. X-ray absorption spectra were merged and normalized using the Athena program ${ }^{25}$ and EXAFS data were extracted using the XAFS program. ${ }^{26} \mathrm{Fe}$ and As K-edge $k^{3} \chi(k)$ EXAFS functions were least-squares fit using theoretical phase and amplitude function calculated with the Feff 8 code. ${ }^{27}$ This shell-by-shell least-squares fitting was performed using previously reported procedures detailed in the SI. ${ }^{5,22,28}$ In addition to shell-by-shell fitting analysis, EXAFS data at the Fe K-edge were analyzed using a linear combination fit (LCF) procedure. For this purpose, we used a set of EXAFS spectra of relevant model compounds, including synthetic Fh2L, synthetic Si-ferrihydrite (Fh-Si) and synthetic goethite ${ }^{5}$ as well as biogenic schwertmannite sample 510B. ${ }^{29}$ Additional simulated reference spectra (calculated Fh-Al and calculated Schw-Al) were used in the LCF procedure to take into account for possible $\mathrm{Al}$ substitution in theses mineral phases, as detailed in (SI Table SI-5 and Figure SI-11). LCF components with contributions lower than $5 \%$ were considered as non significant. ${ }^{30}$ Adding an overall Debye-Waller factor to fit the spectra recorded at $77 \mathrm{~K}$ using model compounds spectra recorded at $10 \mathrm{~K}$ did not improve the fit and yields fit results within the estimated error of $\pm 20 \%$ on fitting components. Both least-squares shell-byshell fits and LCF fits were performed in $k$-space. 


\section{RESULTS}

Mineralogy and Chemistry of the Amous River Sediments. XRD patterns of the sediments collected in March and May 2003 are displayed in Figure 1, and indicate
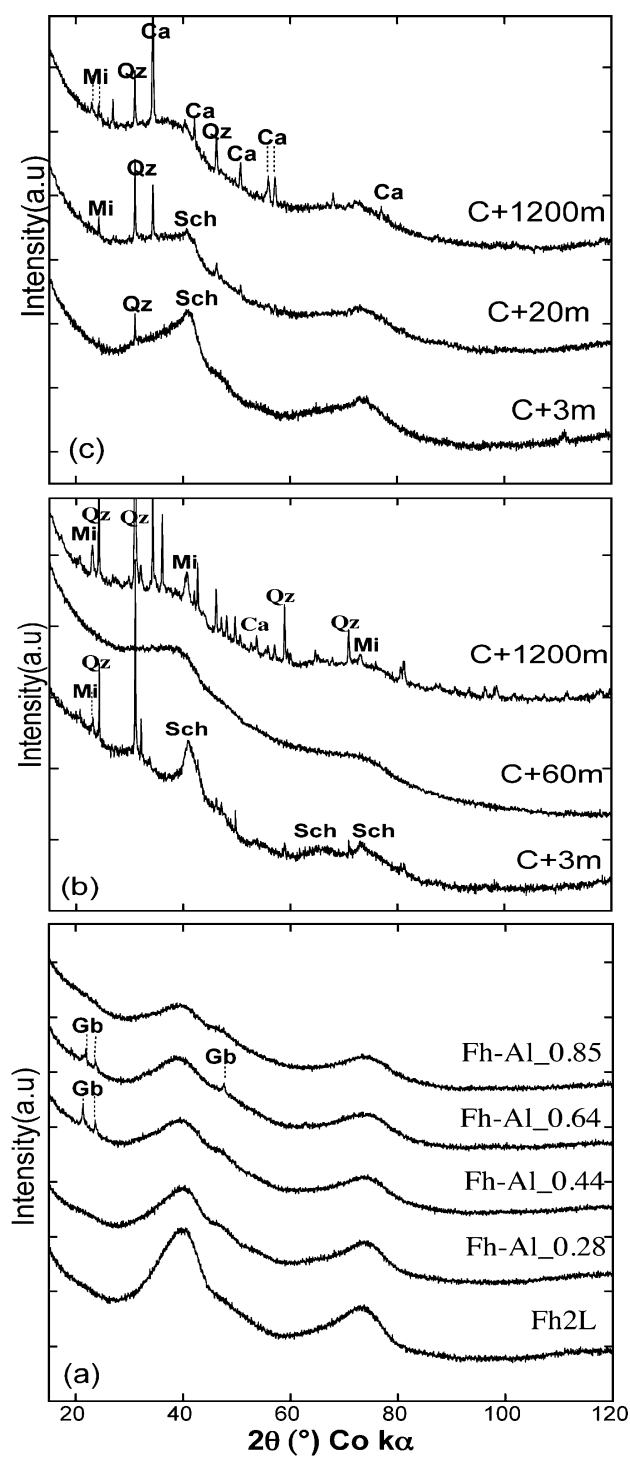

Figure 1. Powder XRD patterns of (a) synthetic Al-Fh samples and of sediment samples from the Amous River collected in (b) March 2003 and (c) May 2003. Sch: schwertmannite, Fh: ferrihydrite, Qz: quartz, $\mathrm{Ca}$ : calcite, Mi: micas, Gb: gibbsite. Note the change in the XRD pattern of the synthetic ferrihydrites with increasing $\mathrm{Al}$ content.

that these samples mainly consist of poorly ordered nanocrystalline or amorphous phases. At $3 \mathrm{~m}$ upstream from the confluence, the Reigous Creek sediments consist of As-bearing schwertmannite (Table 1)..$^{20,22}$ At $3 \mathrm{~m}$ downstream from the confluence with the Reigous creek, schwertmannite is still observed in the Amous River sediments in mixture with a poorly ordered phase. Schwertmannite is especially observed in the $\mathrm{C}+3 \mathrm{~m}$ March sample and, to a lower extent in the $\mathrm{C}+3 \mathrm{~m}$ May sample. At $20 \mathrm{~m}$ and $60 \mathrm{~m}$ downstream from the confluence, whatever the season, schwertmannite is not observed. The XRD pattern is dominated by a ferrihydritelike phase characterized by two broad peaks at $2 \theta=36-42^{\circ}$ and $2 \theta=68-72^{\circ}$, which is accompanied by minor detrital minerals including quartz, calcite and trace amounts of clay minerals. At $1200 \mathrm{~m}$ downstream from the confluence, a similar mineralogy is observed with larger amounts of quartz and calcite. The chemical composition of all sediment samples studied is dominated by iron, and to a lesser extent, by aluminum, silica, sulfate and arsenic. Aluminum concentrations in the Amous River sediments in the $\mathrm{C}+3 \mathrm{~m}$ samples, are within the range $7-16$ wt $\% \mathrm{Al}_{2} \mathrm{O}_{3}$, and are thus significantly larger than in the Reigous Creek sediments $\left(0.1-1.5\right.$ wt $\% \mathrm{Al}_{2} \mathrm{O}_{3}$ in the $\mathrm{C}-3 \mathrm{~m}$ samples (SI Table SI-1). Accordingly the molar $\mathrm{Al}$ / Fe ratios increase from the Reigous Creek sediments $(\mathrm{Al} / \mathrm{Fe}=$ 0.00-0.04 in C-3m samples) to the Amous River sediments $(\mathrm{Al} / \mathrm{Fe}=0.21-0.64$ in March an May samples) (SI Table SI-1). However, the major part of the aluminum appears to be associated to the poorly ordered mineral phases, especially in the $\mathrm{C}+60 \mathrm{~m}$ March and $\mathrm{C}+3 \mathrm{~m}$ May samples, for which no ancillary crystalline phases are observed. In parallel with this increase of the $\mathrm{Al}$ content in the solid phase, the dissolved $\mathrm{Al}$ concentration drastically decreases from the Reigous Creek to the Amous River (SI Table SI-2). These results indicate that aqueous $\mathrm{Al}^{3+}$ in the acidic Reigous Creek water precipitates in the Amous River, in relation with a rapid $\mathrm{pH}$ increase from 3-4 to about 6 within the first few meters downstream from the confluence. This rapid $\mathrm{pH}$ increase leads to massive precipitation of poorly ordered Fh-like material, due to rapid oxidation of $\mathrm{Fe}(\mathrm{II})$ to $\mathrm{Fe}$ (III) at circumneutral $\mathrm{pH}^{7}$ and subsequent oversaturation $\left([\mathrm{Fe}]_{\mathrm{aq}}=0.7-59.6 \mathrm{mg} / \mathrm{L}\right.$; SI Table SI-2) with respect to ferric oxyhydroxides. ${ }^{7,20}$ Simultaneous precipitation of $\mathrm{Al}(\mathrm{III})$ upon precipitation of a Fh-like mineral observed by XRD within the first meters after the confluence could thus suggests the formation of Al-bearing $\mathrm{Fh}$ in the Amous River.

Mineralogy and Chemistry of the Natural and Synthetic Aluminous Ferrihydrite Studied. The presence of $\mathrm{Al}$ as a major impurity in the Fhs from the Amous river sediments is confirmed by the homogeneous distribution of $\mathrm{Fe}$ and $\mathrm{Al}$ at the nanoscale, as observed using TEM-EDXS mapping (Figure 2 and SI Figures SI-2-5). Elemental maps also show the presence of $\mathrm{Si}$ as minor impurity in Fh for samples March C+60m (Figure 2) and May C+20m (SI Figure SI-3). The Si content is higher in the May C+1200 sample, besides detrital silicate minerals that were also observed by XRD (SI Figure SI-5). The presence of $S$ is also evidenced in the March $\mathrm{C}+3 \mathrm{~m}$ sample (SI Figure SI-2), which is consistent with the mixture of Fh and schwertmannite observed by XRD. These observations are confirmed by SEM-EDX analyses of the Fh component in the samples studied, which are reported in Table 1 . The typical powder XRD pattern of the poorly ordered phase sampled in the Amous River (e.g., C+60m March; Figure 1b) compares well with those of synthetic Al-bearing ferrihydrite samples, which are characterized by a shoulder at the high angle side of the broad peak at $2 \theta=36-42^{\circ}$ (Figure 1a). At high $\mathrm{Al} / \mathrm{Fe}$ ratio $(\mathrm{Al} / \mathrm{Fe} \geq 0.44)$, the formation of minor amount of gibbsite in mixture with $\mathrm{Fh}$ is observed in the synthetic samples, while for the sediment samples, gibbsite is not detected (Figure 1).

Fe K-Edge EXAFS Spectroscopy Analysis. Thorough inspection of EXAFS spectra for the natural (SI Figures SI-6 and SI-8) and synthetic (SI Figure SI-7) ferrihydrite samples indicates that the presence of aluminum influences the EXAFS signal, especially by decreasing the amplitude of the second neighbor shell around $\mathrm{Fe}$ in the Fourier Transform, with respect to pure ferrihydrite. This trend was confirmed by shell- 
Table 1. Mineralogical Compositions of the Natural and Synthetic Samples Studied and Chemical Compositions of the Ferrihydrite Component Determined from SEM-EDXS Analyses ${ }^{a}$

\begin{tabular}{|c|c|c|c|c|c|c|}
\hline samples & $\mathrm{pH}$ & mineralogy & $\mathrm{S} / \mathrm{Fe}^{a}$ & As $/ \mathrm{Fe}^{a}$ & $\mathrm{Si} / \mathrm{Fe}^{a}$ & $\mathrm{Al} / \mathrm{Fe}^{a}$ \\
\hline \multicolumn{7}{|l|}{ March sed. } \\
\hline $\mathrm{C}-3 \mathrm{~m}$ & 3.4 & Schw & - & - & - & - \\
\hline$C+3 m$ & 6.3 & Fh, Schw & $0.14(3)$ & $0.09(2)$ & $0.05(1)$ & $0.32(3)$ \\
\hline $\mathrm{C}+60 \mathrm{~m}$ & 7.3 & $\mathrm{Fh}, \mathrm{Qz}$ & $0.02(1)$ & $0.07(1)$ & $0.13(6)$ & $0.53(8)$ \\
\hline $\mathrm{C}+1200 \mathrm{~m}$ & 7.8 & $\mathrm{Fh}, \mathrm{Qz}, \mathrm{Ca}+\mathrm{Mi}$ & $0.02(1)$ & $0.06(2)$ & $0.28(4)$ & $0.34(7)$ \\
\hline \multicolumn{7}{|l|}{ May sed. } \\
\hline $\mathrm{C}-3 \mathrm{~m}$ & 4.9 & Schw & - & - & - & - \\
\hline$C+3 m$ & - & Fh, Schw & $0.02(1)$ & $0.09(3)$ & $0.21(7)$ & $0.25(7)$ \\
\hline $\mathrm{C}+20 \mathrm{~m}$ & 7.4 & Fh, Qz, Ca & $0.03(2)$ & $0.07(1)$ & $0.14(4)$ & $0.36(1)$ \\
\hline$C+1200 m$ & 8.1 & $\mathrm{Fh}, \mathrm{Qz}, \mathrm{Ca}+\mathrm{Mi}$ & $0.01(1)$ & $0.06(1)$ & $0.28(5)$ & $0.43(5)$ \\
\hline \multicolumn{7}{|l|}{ Synthetic Fh } \\
\hline $\mathrm{Fh} 2 \mathrm{~L}$ & $7.8^{b}$ & $\mathrm{Fh}$ & - & - & - & 0 \\
\hline Fh-Al_0.28 & $7.4^{b}$ & $\mathrm{Fh}$ & - & - & - & $0.28(4)$ \\
\hline Fh-Al_o.44 & $7.4^{b}$ & $\mathrm{Fh}, \mathrm{Gb}$ & - & - & - & $0.44(3)$ \\
\hline Fh-Al_0.64 & $7.6^{b}$ & $\mathrm{Fh}, \mathrm{Gb}$ & - & - & - & $0.64(5)$ \\
\hline Fh-Al_0.85 & $7.6^{b}$ & $\mathrm{Fh}, \mathrm{Gb}$ & - & - & - & $0.85(5)$ \\
\hline
\end{tabular}

${ }^{a}$ Data are reported as molar ratio. Schw: Schwertmannite, Fh: Ferrihydrite, Mi: Mica, Qz: Quartz, Ca: Calcite and Gb: Gibbsite, Sed.: sediments. Full chemical compositions of the bulk samples are reported in SI Table SI-1. " - ": not determined. ${ }^{b}$ final synthesis pH.

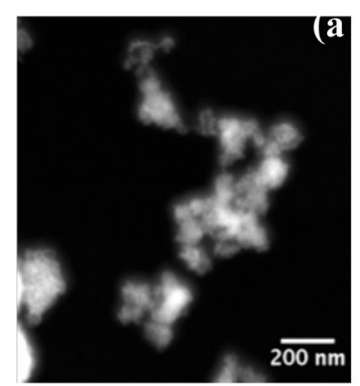

$\mathrm{Fe}$

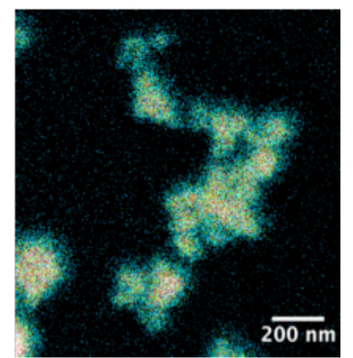

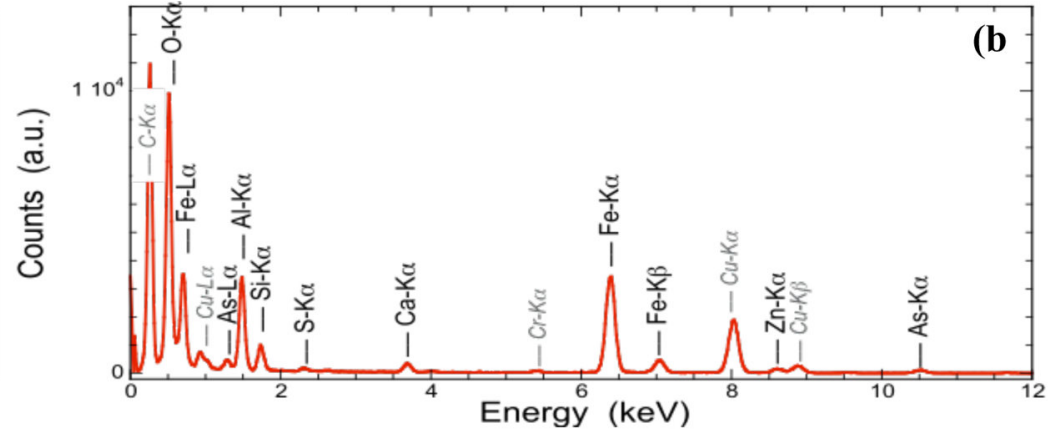

Al
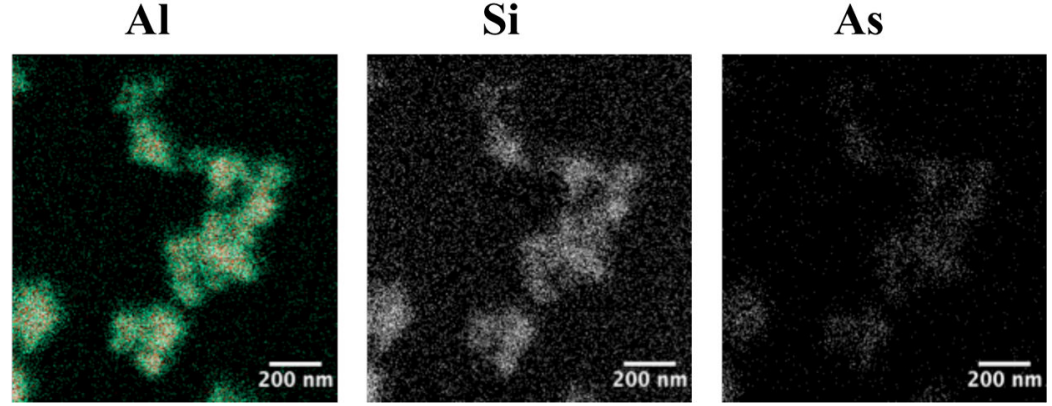

Figure 2. Transmission electron microscopy elemental maps of a Ferrihydrite aggregate (sample C+60m March), showing compositional homogeneity in $\mathrm{Fe}, \mathrm{Al}, \mathrm{Si}$, and As (a) STEM-HAADF image, (b) XEDS spectrum corresponding to the area observed.

by-shell analysis of the EXAFS data as detailed in SI (Tables SI3 and SI-4). However, fitting solutions with $\mathrm{Fe}-\mathrm{Al}$ paths were found to be not reliable for interpreting the EXAFS data of our natural (SI Figure SI-9) and synthetic Al-bearing Fh. Indeed, similar solutions including $\mathrm{Fe}-\mathrm{Al}$ paths can fit the spectrum for $\mathrm{Al}$-free ferrihydrite as shown in the SI (Figure SI-10), which precludes the use of such combination of shells to evaluate the occurrence of $\mathrm{Al}$ neighbors. Consequently, we implemented another approach based on linear combination fitting using end-member spectra, as discussed below.

The Fe K-edge EXAFS data of synthetic and natural samples studied were analyzed using a Linear Combination Fitting (LCF) procedure over the $2-15 \AA^{-1} k$-range. Model compound EXAFS spectra used for these fits (SI Figure SI-11, Table SI-5) included experimental spectra of Al-free 2-line ferrihydrite $(\mathrm{Fh} 2 \mathrm{~L})^{5}$ and Al-free schwertmannite, ${ }^{29}$ Si-rich ferrihydrite (Fh$\mathrm{Si}$ ) as well as theoretical spectra calculated for hypothetical aluminous end-members of 2-line ferrihydrite (Calc_Fh-Al) and schwertmannite (Calc_Schw-Al). These theoretical spectra were used in the LCF procedure in order to take into account for the possible presence of aluminum replacing iron in the ferrihydrite or schwertmannite structures (SI Figure SI-11). For ferrihydrite, this theoretical Fe K-edge spectrum referred to as (Calc_Fh-Al) was calculated using the EXAFS shell-by-shell fit parameters $(R, N, \sigma, \Delta E 0)$ obtained for the first and second neighbor shells for Al-free Fh2L (SI Table SI-5; ${ }^{5}$ ), and replacing the second neighbor $\mathrm{Fe}$ atoms by $\mathrm{Al}$ atoms. This calculated spectrum was then used as proxy for $\mathrm{Fe}$ atoms 

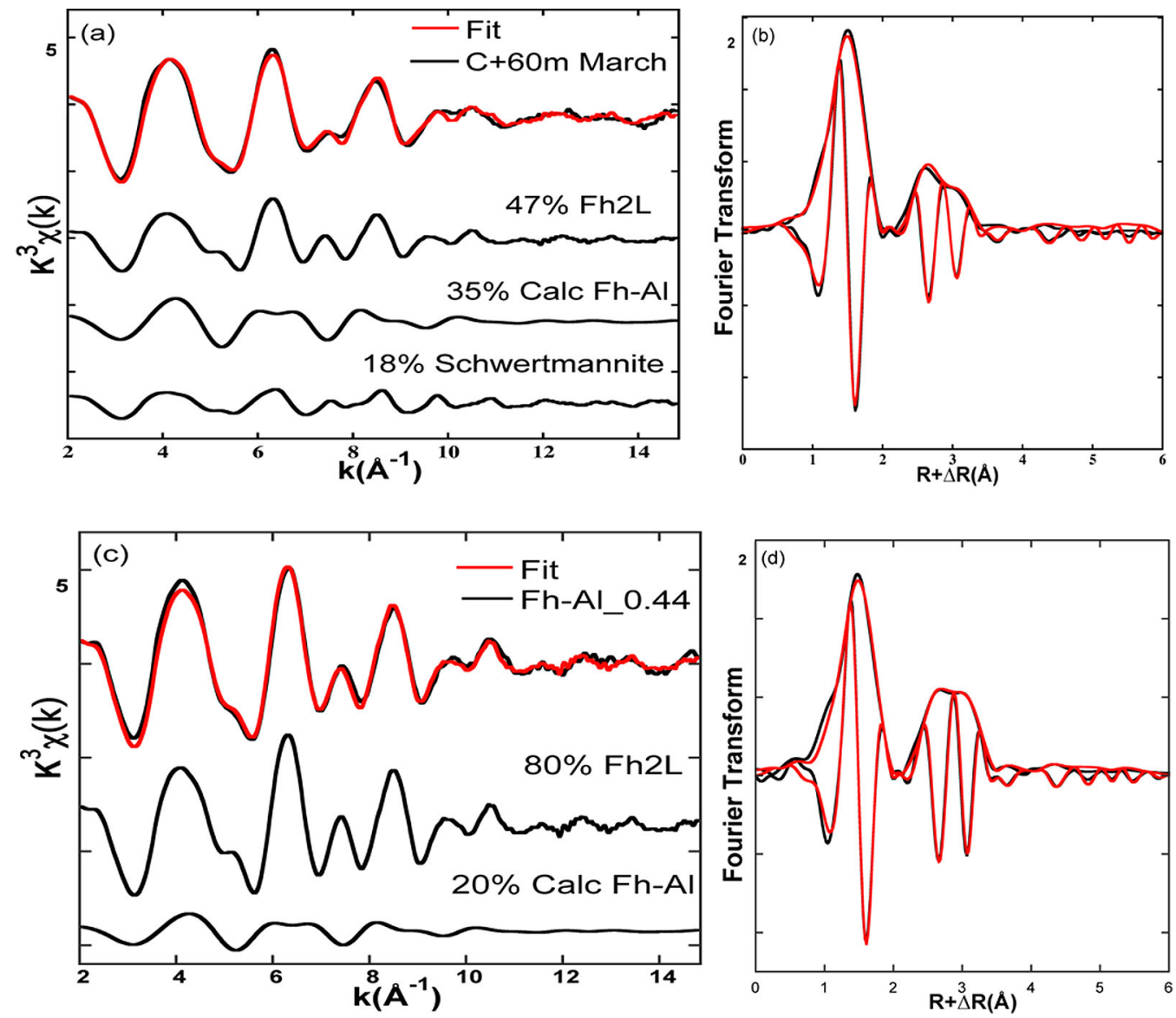

Figure 3. Examples of linear combination fits (LCF) of Fe K-edge EXAFS spectra for a sediment sample (C+60m March) from the Amous River (a) and for a synthetic Al-Fh sample (Fh-Al0.44) (c). Model compound spectra used in these LCF include: synthetic Al-free 2-Lines ferrihydrite (Fh2L), pure natural schwertmannite and a calculated spectrum for $\mathrm{Fe}$ in an ideal aluminous ferrihydrite end-member (Calc Fh-Al). Fourier transforms of the experimental and calculated spectra are shown in (b) and (d).

incorporated in a hypothetical pure Al-ferrihydrite pole. A similar procedure was used to calculate the theoretical Fe Kedge spectrum for Fe atoms incorporated in a hypothetical AlSchwertmannite pole (Calc_Schw_Al) using the shell-by-shell fit parameters reported in SI Table SI-5. ${ }^{22}$ The whole set of Fe K-edge EXAFS data for all natural and synthetic Fh samples studied was successfully fit using these model compound spectra, which indicates that all samples studied consisted dominantly of aluminum substituted ferrihydrite. Examples of LCF analysis of Fe K-edge EXAFS data for the Amous sediment and for synthetic Al-ferrihydrite samples are displayed in Figure 3. LCF fits for all natural and synthetic samples studied are displayed in SI Figures SI-12 and SI-13, respectively. Corresponding proportions of the fitting components are given in SI Table SI-6 and Figure 4. Synthetic aluminous Fh samples were fit using Fh2L (Fe end-member) and calculated Fh-Al ( $\mathrm{Al}$ end-member) as model compounds, with respective proportions of $83-92 \%$ and $15-21 \%$. The Amous River sediment samples were fit with 29-53\% Fh2L, 14-39\% Fh-Al, 17-37\% $\mathrm{Fh}-\mathrm{Si}$, and $11-26 \%$ of an additional schwertmannite component. The $\mathrm{C}+3 \mathrm{~m}$ March sample exhibits a high proportion of the schwertmannite component (56\%), which is consistent with XRD data (Figure 1), and chemical data (S/ $\mathrm{Fe}=0.14$ in Table 1; SI Figure SI-2). For synthetic Al-Fh and natural samples, poor fit solutions were obtained without the Fh-Al (Al end member) component as illustrated in the SI (Figure SI-14 and SI-16). For the natural samples, replacing the schwertmannite component by a goethite or akaganeite component yielded comparable or lower quality fits (SI Figure SI-18). The occurrence of an akaganeite component cannot however be excluded because of the similarity in the local structure of these minerals. ${ }^{31}$ In contrast, the presence of significant amount of goethite can be ruled out since this mineral phase is not observed in XRD data (Figure 1). The occurrence of a schwertmannite/akaganeite (schw/aka) largely explains the peculiar shape of the FT for the natural samples studied, with lower intensity of the $\sim 3.45 \AA$ peak compared to the $\sim 3.00 \AA$ peak. Indeed, LCF fits without this schw/aka component yield virtually equal intensities for these two peaks, as expected for $\mathrm{Al}$-free ferrihydrite (SI Figure SI-14a,b). ${ }^{5}$ Finally, replacing the $\mathrm{Fh}-\mathrm{Al}$ component by a Fh-Si component yields poor fits (SI Figure SI-15). However, adding this fourth component to the Fh2L, Fh-Al and Schw improves the fit for the May samples and the March C+1200m sample, but not for the March $C+3 \mathrm{~m}$ and $\mathrm{C}+60 \mathrm{~m}$ samples (SI Figure SI-14e,f).

X-ray Absorption Spectroscopy at the As K-Edge. Arsenic oxidation state in the Amous River sediment samples was determined using linear combination fit of X-ray absorption near edge structure (XANES) spectra at the As K-edge. Experimental spectra of two amorphous $\mathrm{As}(\mathrm{III})-\mathrm{Fe}(\mathrm{III})$ and $\mathrm{As}(\mathrm{V})-\mathrm{Fe}(\mathrm{III})$ oxyhydroxides model compounds ${ }^{32}$ were used as spectral components in this LCF analysis. Results indicates that $\mathrm{As}(\mathrm{V})$ is the dominant species in all sediments studied and is accompanied by various proportions of As(III) (9-38\% ; SI 

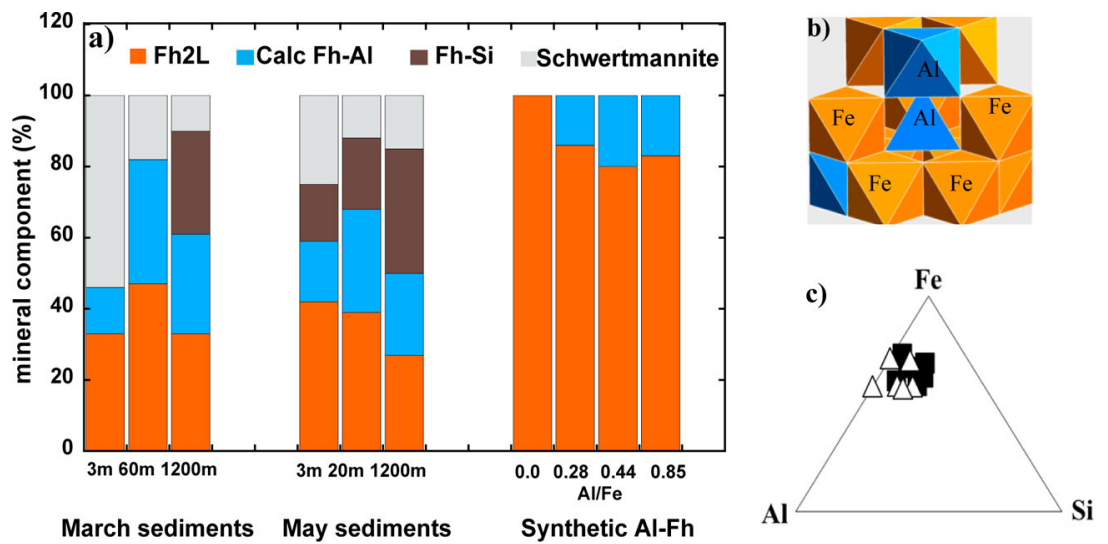

Figure 4. Normalized proportions of mineral components determined by LCF analysis of Fe K-edge EXAFS spectra for the Amous River sediments samples from March 2003 and May 2003, and for synthetic Al-free and Al-bearing ferrihydrite samples (Syn Fh-Al). (a) Model compound spectra used in these LCF include synthetic 2-Lines ferrihydrite (Fh2L), synthetic Si-rich ferrihydrite (Fh-Si), synthetic schwertmannite, ${ }^{29}$ and a calculated spectrum for $\mathrm{Fe}$ in an aluminous ferrihydrite end-member (Calc $\mathrm{Fh}-\mathrm{Al}$ ). The proportion of this latter aluminous component is interpreted as the molar content of aluminum in the structure of the studied ferrihydrite samples. Fit results are reported in SI Table SI-6. (b) A possible structural model for aluminous ferrihydrite with a $\delta$-Keggin-like local structure is presented. (c) Ternary diagram comparing the Al, Fe and Si molar content of the natural ferrihydrite samples studied, as derived from LCF-EXAFS analysis (white triangles) and from SEM-EDXS analyses (black squares) (see text and SI Table SI-6).

Figure SI-19). EXAFS analysis at the As K-edge was then conducted on sediments samples with the highest $\mathrm{As}(\mathrm{V})$ content in order to determine the molecular environment of arsenate in these samples. These data were compared with EXAFS spectra collected on synthetic samples corresponding to arsenate sorbed onto $\mathrm{Al}$-free and Al-bearing Fh samples in order to evaluate the influence of aluminum on the nature of arsenic surface complexes. Results of the shell-by-shell fit of unfiltered $k^{3}$-weighted EXAFS spectra for the natural and synthetic samples are displayed in (Figure 5), and corresponding fitting parameters are given in SI Table SI-7. As K-edge EXAFS spectra of the As(V)-rich sediment samples from May compare well with those of $\mathrm{As}(\mathrm{V})$ adsorbed onto synthetic Fh2L and Al-Fh samples (Figure 5). For all samples, the firstneighbor contribution to the EXAFS was fit with $4.0 \pm 0.4$ oxygen atoms at $1.69 \pm 0.02 \AA$, in agreement with the geometry of the arsenate tetrahedron. The second-neighbor contributions to the EXAFS were fit with $1.3 \pm 0.3 \mathrm{Fe}$ atoms at a distance of $3.28 \pm 0.02 \AA$ (SI Table SI-7). An additional multiple-scattering (MS) contribution corresponding to the twelve As-O-O paths at $3.10 \pm 0.05 \AA$ within the $\mathrm{AsO}_{4}$ tetrahedron was added in all fits, as reported in previous studies. ${ }^{22,28}$ All attempts to include an As-Al scattering path in the fit, either replacing the As-Fe path or in addition to the As-Fe path, did not significantly improve the fits for all samples, as illustrated in Figure SI-20 for the C+3m May sample. The observed As-Fe distance at $3.28 \pm 0.02 \AA$ can be interpreted as a bidentate binuclear double-corner $\left({ }^{2} C\right)$ arsenate surface complex forming on synthetic aluminous ferrihydrite as well as on the natural AlFh and/or schwertmannite samples studied. Such an arsenic complex has already been classically reported for $\mathrm{As}(\mathrm{V})$ sorbed on, or coprecipitated with, $\mathrm{Fe}$ (III) oxyhydroxides ${ }^{28,33}$ and oxyhydroxysulfates. $^{22}$

\section{DISCUSSION}

Evidence for Aluminum Substitution in the Natural Ferrihydrites. Due to similar valence and close ionic radii $\left(0.54 \AA\right.$ for ${ }^{\mathrm{VI}} \mathrm{Al}^{3+}$ vs $0.65 \AA$ for $\left.{ }^{\mathrm{VI}} \mathrm{Fe}^{3+}\right), \mathrm{Al}^{3+}$ is known to often substitute for $\mathrm{Fe}^{3+}$ in iron oxides and oxyhydroxides ${ }^{7}$ and the aluminum substitution rate can reach $20-30 \mathrm{~mol} \% \mathrm{Al}$ in
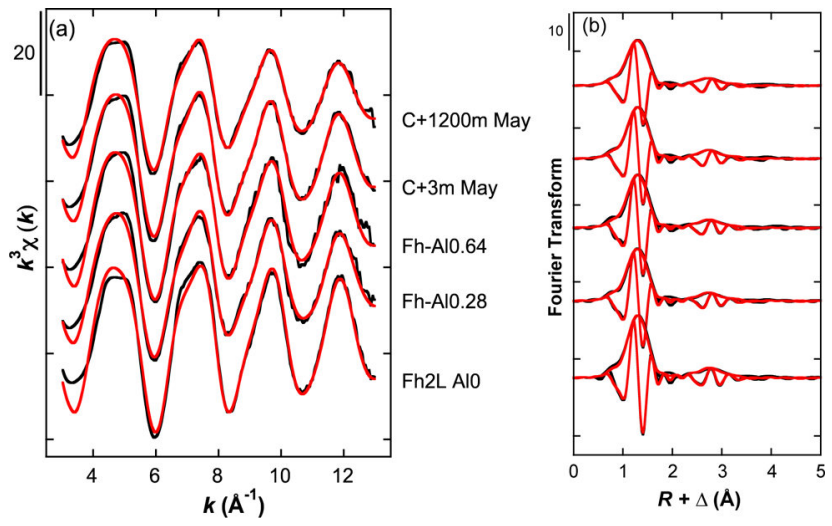

Figure 5. Arsenic K-edge EXAFS spectra of Amous river sediment samples $(\mathrm{C}+3 \mathrm{~m}$ and $\mathrm{C}+1200 \mathrm{~m}$ May) compared to EXAFS data for As(V) sorbed on synthetic Fh (Fh2L Al0) and Fh-Al (Fh-Al0.28 and FhAl0.64) samples: (a) Results of the shell-by-shell fits of unfiltered $k^{3}$ weighed EXAFS data. (b) Corresponding Fourier transforms (FT), including the magnitude and imaginary part. Experimental and calculated curves are displayed as black and red lines, respectively. All fit parameters are reported in SI Table SI-7. Beyond the first coordination oxygen shell around arsenic, fit results indicate a single As-Fe correlation at a distance of $3.28 \pm 0.02 \AA$.

synthetic ferrihydrite as recently demonstrated by Cismasu et al., ${ }^{17}$ based on wide-angle X-ray scattering methods. The identification of $\mathrm{Al}$-substitution in natural ferrihydrite using scattering based methods might be difficult when this mineral phase occurs in mixture with other compounds. In the present study, we show that EXAFS analysis can be well suited for identifying such aluminous disordered phases. Indeed, our LCF analysis of Fe K-edge EXAFS data for both synthetic and natural sediment samples showed that $\mathrm{Al}$-free $\mathrm{Fh}$ can be distinguished from Al-bearing $\mathrm{Fh}$. In addition this LCF procedure yields an estimate of the extent of aluminum substitution in the structure. In the synthetic aluminous ferrihydrite from the present study, the aluminum content is found to be limited to $14-20 \mathrm{~mol} \% \mathrm{Al}$, regardless of the initial aqueous $\mathrm{Al} / \mathrm{Fe}$ molar ratio. Such limitation could be related to 
the formation of $\mathrm{Al}$-hydroxide such as gibbsite, $\alpha-\mathrm{Al}(\mathrm{OH})_{3}$, as a separate phase at $\mathrm{Al} / \mathrm{Fe} \geq 0.44$ (Figure 1), which was also observed by Cismasu et al. ${ }^{17}$ In contrast to the synthetic samples studied here, the natural ferrihydrite samples collected in the Amous River exhibit high $\mathrm{Al}$ content as suggested by chemical analysis $(\mathrm{Al} / \mathrm{Fe}+\mathrm{Al}+\mathrm{Si}=25 \pm 10 \mathrm{~mol} \%$; SI Table SI$6)$ and as confirmed by EXAFS LCF analysis $(\mathrm{Al} / \mathrm{Fe}+\mathrm{Al}+\mathrm{Si}=$ $30 \pm 12 \mathrm{~mol} \%$; SI Table SI-6), without any evidence for the formation of gibbsite. The proportion of $\mathrm{Si}$ associated to these natural ferrihydrite range from $4-17 \mathrm{~mol} \%$ as indicated by SEM-EDXS and EXAFS results (SI Table SI-6). This composition range is illustrated in the ternary diagram displayed in Figure 4. This high proportion of substituted $\mathrm{Al}$ in the natural ferrihydrite samples studied approaches the highest $\mathrm{Al}$ substitution observed by Cismasu et al. ${ }^{17}$ in synthetic aluminous $\mathrm{Fh}$ (20-30 mol \%Al). The lower aluminum substitution rate observed in our synthetic Al-Fhs could be explained by the rapid synthesis method ( $30 \mathrm{~min}$ titration to $\mathrm{pH} 7-8$ followed by immediate centrifugation and drying) compared to the $24 \mathrm{~h}$ aging time at final $\mathrm{pH} 7.5$ used by Cismasu et al. ${ }^{17}$ before centrifugation. Similar aging effects could also occur for the natural Fh samples studied after they deposited at the bottom of the Amous River. In addition, these natural Fh samples contain silica as another major impurity (46 wt \% in samples containing no crystalline silicates (SI Table SI-1) which may affect the local ferrihydrite structure, especially in inhibiting double-corner $\mathrm{Fe}-\mathrm{Fe}$ linkage at $\sim 3.45 \AA^{24,34,35}$ However, the presence of $19 \pm 7 \%$ of the schw/aka component in these natural samples makes its difficult to evaluate such effect of silica on their local structure.

Origin of Aluminous Ferrihydrite in the Amous River. Aluminous $\mathrm{Fh}$ is absent in the suspended matter and the bottom sediments of the Reigous River upstream from the confluence, these latter consisting essentially of schwertmannite. $^{20-22}$ The Reigous creek is the major source of dissolved $\mathrm{Fe}(\mathrm{II}), \mathrm{Al}(\mathrm{III}), \mathrm{H}_{3} \mathrm{AsO}_{3}$, and $\mathrm{SO}_{4}{ }^{2-}$ entering the Amous River. ${ }^{20}$ In contrast to the high concentrations of dissolved $\mathrm{Fe}$ (II) in the Reigous creek $3 \mathrm{~m}$ upstream from the confluence $(0.7-60 \mathrm{mg} /$ L) (SI Table SI-2), Fe concentrations after the confluence with the Amous River are often below the detection limit. This drastic drop in aqueous $\mathrm{Fe}$ concentrations is due to the precipitation of ferrihydrite in the first tens of meters downstream the confluence with the alkaline Amous River ( $\mathrm{pH} 7.3-8.4)$. The neutralization of the Reigous water ( $\mathrm{pH} 3-$ 5) to $\mathrm{pH} \geq 6.3$ at $3 \mathrm{~m}$ and $60 \mathrm{~m}$ downstream of the confluence likely favors rapid oxidation of dissolved $\mathrm{Fe}$ (II),${ }^{36,37}$ followed by Fh precipitation. The large fraction of ferrihydrite found in the precipitates formed at $\mathrm{pH}$ up to 6 is consistent with the optimal $\mathrm{pH}$ range to form this phase. ${ }^{38,39}$ Concomitantly, the high $\mathrm{Al}$ concentrations in the Reigous creek at $3 \mathrm{~m}$ upstream from the confluence, ranging from 3 to $16 \mathrm{mg} / \mathrm{L}$, drops rapidly to much lower values $(0.04-0.15 \mathrm{mg} / \mathrm{L})$ downstream the confluence, which can be explained by the 1000 times decrease of the solubility of $\mathrm{Al}$ (hydr)oxides and oxyhydroxides with increasing $\mathrm{pH}$ from 4 to $6 .{ }^{37}$ Consequently, $\mathrm{Al}(\mathrm{III})$ coprecipitates with $\mathrm{Fe}$ (III) to form aluminous $\mathrm{Fh}$ which is the dominant solid phase in the Amous River sediments up to $60 \mathrm{~m}$ downstream of the confluence. The formation of ferrihydrite is favored over a more crystalline phase such as goethite or lepidocrocite, likely because of the high $\mathrm{Fe}$ supersaturation and because of the presence of elevated $\mathrm{Al}$ and $\mathrm{Si}$ concentrations in the Amous River water (SI Table SI-2). This interpretation is supported by the results of Taylor and Schwertmann ${ }^{40}$ who showed that formation of ferrihydrite is favored over crystalline phases at high level of $\mathrm{Al}(\mathrm{Al} / \mathrm{Al}+\mathrm{Fe} \geq 0.4)$ and by the results of Schwertmann and Thalman ${ }^{41}$ who showed that the $\mathrm{Fh}$ is formed at high level of $\mathrm{Si}(\mathrm{Si} / \mathrm{Fe} \leq 0.156)$ instead of lepidocrocite. In a recent study, Burgos et al. ${ }^{19}$ have used LCF of Fe K-edge EXAFS spectra to determine the mineralogy of precipitates forming in a coal mine drainage from central Pennsylvania. Precipitates were found to consist of ferrihydrite forming after abiotic neutralization ( $\mathrm{pH} 4.4-8.4)$ of the mine drainage, with lower amounts of schwertmannite and goethite. Aluminum was detected by SEM-EDS in these abiotic precipitates. In the present study we demonstrate that aluminous $\mathrm{Fh}$ can form upon rapid neutralization of AMD water, and that $\mathrm{Al}$ can substitute for $\mathrm{Fe}$ in the ferrihydrite structure in such natural material. Eventually, transformation of Fh to goethite would be expected after aging at circumneutral $\mathrm{pH}$ in the Amous River far downstream from the confluence. This latter transformation might however be retarded or prevented by high concentrations of impurities, especially $\mathrm{Al}$ and $\mathrm{Si}$, in the sediments. ${ }^{42-44}$

Origin of Schwertmannite in the Amous River Sediments. The present EXAFS analysis shows that a schwertmannite/akaganeite component occurs in association with aluminous ferrihydrite in the sediments of the Amous River (Figure 3). XRD and EXAFS results indicate the occurrence of a large amount of schwertmannite in the sample collected at $3 \mathrm{~m}$ downstream of the confluence in March (C $+3 \mathrm{~m}$ March). The occurrence of schwertmannite downstream of the confluence is likely explained by direct particle transport from the Reigous Creek since the relatively low dissolved $\mathrm{SO}_{4}{ }^{2-}$ concentrations $(60-225 \mathrm{mg} / \mathrm{L})$ in the Amous River as well as the $\mathrm{pH}$ values up to 6.3 are not favorable to the formation of this phase. ${ }^{38}$ In addition, our EXAFS results suggest the absence of aluminum substitution in the schwertmannite from the Amous River sediments (SI Figure SI-17), which supports the fact that this phase forms before the confluence and is transported to the Amous River. Apart from the schwertmannite-rich sample ( $\mathrm{C}+3 \mathrm{~m}$ March), the proportion of the schw/aka component over total iron, as determined by EXAFS LCF, remains within the $20-30 \%$ range in the Amous River sediments as far as $1200 \mathrm{~m}$ downstream from the confluence (SI Table SI-6). Sulfate concentration in these sediments (S/Fe $=0.01-0.02$; SI Table SI-1) are slightly lower than those expected for a mixture of sulfate-free ferrihydrite with $20-30 \%$ schwertmannite $\left(\mathrm{S} / \mathrm{Fe}=0.19 \pm 0.03^{38}\right)$, which would fall in the range $\mathrm{S} / \mathrm{Fe}=0.025-0.07$. This lower sulfate content could be explained by the occurrence of a minor akaganeite component, which is not excluded regarding the elevated chloride concentrations found in the Reigous Creek and in the Amous River waters (SI Table SI-2). The absence of goethite peaks in XRD patterns of the studied sediments suggests that the expected transformation of schwertmannite to goethite after aging at circumneutral $\mathrm{pH}$, as previously reported ${ }^{38,45-48}$ is slow or even prevented in the natural system studied here. Indeed, although this transformation requires several years under acidic conditions, ${ }^{38,45,46}$ it is faster at near-neutral $\mathrm{pH}$ and requires no more than 100 days. $^{45-48}$ In addition this transformation rate can be slowed by constituents or impurities able stabilize schwertmannite such as sulfate or organic carbon. $^{48}$ In the sediments studied here, schwertmannite could be stabilized by the presence of silica. ${ }^{4}$

Reactivity of Aluminous Ferrihydrite. The role of $\mathrm{Al}-$ bearing hydrous $\mathrm{Fe}$ oxides in the scavenging of trace metals in 
natural systems was discussed in a previous study by Burgos et al. ${ }^{19}$ Natural occurrence of Al-rich ferrihydrite has been also already observed ${ }^{18}$ but $\mathrm{Al}$ for $\mathrm{Fe}$ substitution in ferrihydrite has yet only been demonstrated in synthetic samples. ${ }^{17}$ The present study yields the first direct evidence for the scavenging of arsenic by natural aluminous ferrihydrite forming after neutralization of acidic mine waters, with high As/Fe ratios within the range $0.05-0.07 \mathrm{~mol} / \mathrm{mol}$. Arsenic K-edge EXAFS data of the solid sediment samples show that arsenic mainly occur as adsorbed As $(\mathrm{V})$, with evidence for the formation of inner-sphere complexes at the Al-ferrihydrite surface. Such an arsenic complex has already been classically reported for As(V) sorbed on, or coprecipitated with, iron(III) oxyhydroxides. ${ }^{28,33}$ Occurrence of As(V) outer-sphere complexes ${ }^{49}$ can however not be excluded since these species cannot be easily detected using EXAFS spectroscopy when inner-sphere complexes occur in the same sample. ${ }^{50}$ The absence of $\mathrm{As}-\mathrm{Al}$ contribution in our fits of the As K-edge EXAFS data for both natural and synthetic samples studied suggests that arsenate is mainly bound to $\mathrm{Fe}$ atoms at the surface of the aluminous Fh studied. However, the binding of arsenate to aluminum atoms cannot be excluded, especially because As-Al contributions to the EXAFS are expected to be out-of-phase with As-Fe contributions for As-cation distances within the 3.1-3.3 $\AA$ range. Despite the similar EXAFS signatures obtained for As(V) sorbed onto Alsubstituted and Al-free ferrihydrites, the question arises whether the surface reactivity of ferrihydrite could be modified by structural incorporation of $\mathrm{Al}$. However, the literature reveals inconsistencies as to whether Al-containing Fhs or Al-free Fhs samples are the most effective for arsenic removal. ${ }^{15,51-53}$ Although this particular issue would need further investigations, the present study shows that aluminous ferrihydrite may play an important role in scavenging arsenic in mining environments. It thus yields new perspective for understanding the reactivity and stability of this mineral phase in the environment.

\section{ASSOCIATED CONTENT}

\section{Supporting Information}

Additional information as noted in the text. This material is available free of charge via the Internet at http://pubs.acs.org.

\section{AUTHOR INFORMATION}

\section{Corresponding Author}

*E-mail: guillaume.morin@impmc.upmc.fr.

\section{Notes}

The authors declare no competing financial interest.

\section{ACKNOWLEDGMENTS}

We dedicate this article to our late colleague and friend Philippe Ildefonse who initiated the studies on ferrihydrite at the IMPMC in the $90^{\prime}$ s. The authors are indebted to Udo Schwertmann who kindly provided the reference schwertmannite sample $510 \mathrm{~B}^{28}$ to Philippe Ildefonse who recorded the EXAFS spectrum of this sample in 1998. The authors are indebted to Marc Leblanc for having kindly provided the TOC picture of the confluence zone. We acknowledge ESRF, LURE, and ELETTRA for provision of beamtime on beamlines BM30B, D44, and XAFS, respectively. Olivier Proux (ESRF), Jean-Louis Hazemann (ESRF), Denis Testemale (ESRF), Valerie Briois (LURE/SOLEIL) Stephanie Belin (LURE/ SOLEIL), Andrea Cognigi (ELETTRA), Luca Olivi (ELETTRA) are kindly acknowledged for their help in acquiring
EXAFS data on these synchrotron beamlines. We thank Imene Estève for her help in semiquantitative SEM-EDXS analyses at IMPMC. This work was supported by the CNRS - EC2CO national program and by SESAME IdF grant \#1775.

\section{REFERENCES}

(1) Smedley, P. L.; Kinniburgh, D. G. A review of the source, behaviour and distribution of arsenic in natural waters. Appl. Geochem. 2002, 17, 517-568.

(2) Morin, G.; Calas, G. Arsenic in soils, mine tailings, and former industrial sites. Elements 2006, 2, 97-101.

(3) Michel, F. M.; Ehm, L.; Antao, S. M.; Lee, P. L.; Chupas, P. J.; Liu, G.; Strongin, D. R.; Schoonen, M. A. A.; Phillips, B. L.; Parise, J. B. The structure of ferrihydrite, a nanocrystalline material. Science 2007, 316, 1726-1729.

(4) Michel, F. M.; Barron, V.; Torrent, J.; Morales, M. P.; Serna, J. N.; Boily, J.-F.; Liu, Q.; Ambrosini, A.; Cismasu, A. C.; Brown, G. E., Jr. Ordered ferromagnetic form of ferrihydrite reveals links among structure, composition, and magnetism. Proc. Natl. Acad. Sci. U.S.A. 2010, 107, 2787-2792.

(5) Maillot, F.; Morin, G.; Wang, Y.; Bonnin, D.; Ildefonse, P.; Chaneac, C.; Calas, G. New insight into the structure of nanocrystalline ferrihydrite: EXAFS evidence for tetrahedrally coordinated iron(III). Geochim. Cosmochim. Acta 2011, 75, 2708-2720.

(6) Guyodo, Y.; Sainctavit, P.; Arrio, M. A.; Carvallo, C.; Penn, R. L.; Erbs, J. J.; Forsberg, B. S.; Morin, G.; Maillot, F.; Lagroix, F.; Bonville, P.; Wilhelm, F.; Rogalev, A. X-ray magnetic circular dichroïsm provides strong evidence for tetrahedral iron in ferrihydrite. Geochem. Geophys. Geosyst. 2012, 13, Q06Z44.

(7) Cornell, R. M.; Schwertmann, U. The iron oxides: Structure, properties, reactions, occurrences and uses; Wiley-VCH: Darmstadt, 2003.

(8) Dixit, S.; Hering, J. G. Comparison of $\operatorname{arsenic}(\mathrm{V})$ and arsenic(III) sorption onto iron oxide minerals: Implications for arsenic mobility. Environ. Sci. Technol. 2003, 37, 4182-4189.

(9) Fitzpatrick, R. W.; Schwertmann, U. Al-substituted goethite-An indicator of pedogenic and other weathering environments in South Africa. Geoderma. 1982, 27, 335-347.

(10) Schwertmann, U.; Carlson, L. Aluminum influence on ironoxides. 17. Unit-cell parameters and aluminum substitution of natural goethites. Soil Sci. Soc. Am. J. 1994, 58, 256-261.

(11) Thiel, R. Zum System $\alpha-\mathrm{FeOOH}-\alpha-\mathrm{AlOOH}$. Z. Anorg. Allg. Chem. 1963, 326, 70-78.

(12) Schwertmann, U.; Fitzpatrick, R. W.; Taylor, R. M.; Lewis, D. G. The influence of aluminum on iron oxides. Part II. Preparation and properties of Al-substituted hematites. Clays Clay Miner. 1979, 27, $105-112$.

(13) Da Costa, G. M.; Van San, E.; De Grave, E.; Vandenberghe, R. E.; Barrón, V.; Datas, L. Al hematites prepared by homogeneous precipitation of oxinates: Material characterization and determination of the Morin transition. Phys. Chem. Miner. 2002, 29, 122-131.

(14) Chadwick, J. C.; Jones, D. H.; Thomas, M. F.; Tatlock, G. J.; Devenish, R. W. A Mössbauer study of ferrihydrite and aluminium substituted ferrihydrites. J. Magn. Magn. Mater. 1986, 61, 88-100.

(15) Masue, Y.; Loeppert, R. H.; Kramer, T. A. Arsenate and arsenite adsorption and desorption behavior on coprecipitated aluminum:iron hydroxides. Environ. Sci. Technol. 2007, 41, 837-842.

(16) Jain, A.; Sharma, K.V.; Mbuya, S. O. Removal of arsenite by $\mathrm{Fe}(\mathrm{VI}), \mathrm{Fe}(\mathrm{VI}) / \mathrm{Fe}(\mathrm{III})$, and $\mathrm{Fe}(\mathrm{VI}) / \mathrm{Al}(\mathrm{III})$ salts: Effect of $\mathrm{pH}$ and anions. J. Hazard. Mater. 2009, 169, 339-344.

(17) Cismasu, A. C.; Michel, F. M.; Stebbins, J. F.; Levard, C.; Brown, G. E., Jr. Properties of impurity-bearing ferrihydrite. I. Effects of $\mathrm{Al}$ content and precipitation rate on the structure of 2-line ferrihydrite. Geochim. Cosmochim. Acta 2012, 92, 275-291.

(18) Cismasu, A. C.; Michel, F. M.; Tcaciuc, A. P.; Tyliszczak, T.; Brown, G. E., Jr. Composition and structural aspects of naturally occurring ferrihydrite. C. R. Geosci. 2011, 343, 210-218. 
(19) Burgos, W. D.; Borch, T.; Troyer, L. D.; Luan, F.; Larson, L. N.; Brown, J. F.; Lambson, J.; Shimizu, M. Schwertmannite and Fe oxides formed by biological low-pH $\mathrm{Fe}$ (II) oxidation versus abiotic neutralization: Impact on trace metal sequestration. Geochim. Cosmochim. Acta 2011, 76, 29-44.

(20) Casiot, C.; Lebrun, S.; Morin, G.; Bruneel, O.; Personné, J. C.; Elbaz-Poulichet, F. Sorption and redox processes controlling arsenic fate and transport in a stream impacted by acid mine drainage. Sci. Total Environ. 2005, 347, 122-130.

(21) Egal, M.; Casiot, C.; Morin, G.; Elbaz-Poulichet, F.; Cordier, M. A.; Bruneel, O. An updated insight into the natural attenuation of As concentrations in Reigous creek (southern France). Appl. Geochem. 2010, 25 (12), 1949-1957.

(22) Maillot, F.; Morin, G.; Juillot, F.; Bruneel, O.; Casiot, C.; OnaNguema, G.; Wang, Y.; Lebrun, S.; Aubry, E.; Vlaic, G.; Brown, G. E., Jr. Structure and reactivity of As(III)- and As(V)-rich schwertmannites and amorphous ferric arsenate sulfate from the Carnoulès acid mine drainage, France: Comparison with biotic and abiotic model compounds and implications for As remediation. Geochim. Cosmochim. Acta 2013, 104, 310-329.

(23) Schwertmann, U.; Cornell, R. M. Iron Oxides in the Laboratory: Preparation and Characterization; VCH: New York, 1991.

(24) Voegelin, A.; Kaegi, R; Frommer, J.; Vantelon, D.; Hug, S. J. Effect of phosphate, silicate, and $\mathrm{Ca}$ on $\mathrm{Fe}(\mathrm{III})$-precipitates formed in aerated $\mathrm{Fe}$ (II)- and $\mathrm{As}(\mathrm{III})$-containing water studied by $\mathrm{X}$-ray absorption spectroscopy. Geochim. Cosmochim. Acta 2010, 74, 164186.

(25) Ravel, B.; Newville, M. ATHENA, ARTEMIS, HEPHAESTUS: Data analysis for X-ray absorption spectroscopy using IFEFFIT. J. Synch. Rad. 2005, 12, 537-541.

(26) Winterer, M. XAFS - a data analysis program for material science. J. Phys. (Paris) 1997, IV 7, 243-244.

(27) Ankudinov, A. L.; Ravel, B.; Rehr, J. J.; Conradson, S. D. Realspace multiple-scattering calculation and interpretation of X-rayabsorption near-edge structure. Phys. Rev. B 1998, 58, 7565-7576.

(28) Hohmann, C.; Morin, G.; Ona-Nguema, G.; Guigner, J. M.; Brown, G. E., Jr.; Kappler, A. Molecular-level modes of As binding to $\mathrm{Fe}(\mathrm{III})$ (oxyhydr)oxides precipitated by the anaerobic nitrate-reducing $\mathrm{Fe}(\mathrm{II})$-oxidizing Acidovorax sp. strain BoFeN1. Geochim. Cosmochim. Acta 2011, 75, 4699-4712 (2011).

(29) Bigham, J. M.; Schwertmann, U.; Carlson, L.; Murad, E. A poorly crystallized oxyhydroxysulfate of iron formed by bacterial oxidation of $\mathrm{Fe}(\mathrm{II})$ in acid mine waters. Geochim. Cosmochim. Acta 1990, 54, 2743-2758.

(30) Cancès, B.; Juillot, F.; Morin, G.; Laperche, V.; Alvarez, L.; Proux, O.; Hazemann, J. L.; Brown, G. E., Jr.; Calas, G. XAS evidence of $\mathrm{As}(\mathrm{V})$ association with iron oxyhydroxides in a contaminated soil at a former arsenical pesticide processing plant. Environ. Sci. Technol. 2005, 39, 9398-9405.

(31) Fernandez-Martinez, A.; Timon, V.; Roman-Ross, G.; Cuello, G. J.; Daniels, J. E.; Ayora, C. The structure of schwertmannite, a nanocrystalline iron oxyhydroxysulfate. Am. Mineral. 2010, 95, 13121322.

(32) Morin, G.; Juillot, F.; Casiot, C.; Bruneel, O.; Personné, J.-C.; Elbaz-Poulichet, F.; Leblanc, M.; Ildefonse, Ph; Calas, G. Bacterial formation of tooeleite and mixed arsenic(III) or arsenic(V)-iron(III) gels in the Carnoulès acid mine drainage, France. A XANES, XRD and SEM study. Environ. Sci. Technol. 2003, 37, 1705-1712.

(33) Waychunas, G. A.; Rea, B. A.; Fuller, C. C.; Davis, J. A. Surfacechemistry of ferrihydrite.1 EXAFS studies of thegeometry of coprecipitated and adsorbed arsenate. Geochim. Cosmochim. Acta 1993, 57, 2251-2269.

(34) Pokrovski, G. S.; Schott, J.; Farges, F.; Hazeman, J.-L. Iron(III)silicate interactions in aqueous solution: Insights from $\mathrm{X}$-ray absorption fine structure spectroscopy. Geochim. Cosmochim. Acta 2003, 67, 3559-3573.

(35) Doelsch, E.; Masion, A.; Rose, J.; Stone, W. E. E.; Boterro, J. Y.; Bertsch, P. M. Chemistry and structure of colloids obtained by hydrolysis of $\mathrm{Fe}(\mathrm{III})$ in the presence of $\mathrm{SiO} 4$ ligands. Colloids Surf., A 2003, 217, 121-128.

(36) Singer, P. C.; Stumm, W. The solubility of ferrous iron in carbonate bearing waters. J. Am. Water. Works Ass. 1970, 62, 198-202.

(37) Sigg, L.; Behra, P.; Stumm, W. Chimie Des Milieux Aquatiques, 3rd ed.; Dunod: France2000.

(38) Bigham, J. M.; Schwertmann, U.; Traina, S. J.; Winland, R. L.; Wolf, M. Schwertmannite and the chemical modeling of iron in acid sulfate waters. Geochim. Cosmochim. Acta 1996b, 60, 2111-2121.

(39) Murad, E.; Rojik, P. Iron-rich precipitates in a mine drainage environment: Influence of $\mathrm{pH}$ on mineralogy. Am. Mineral. 2003, 88, 1915-1918.

(40) Taylor, R. M.; Schwertmann, U. The influence of aluminum on iron oxides. Part I. The influence of $\mathrm{Al}$ on $\mathrm{Fe}$ oxide formation from the $\mathrm{Fe}(\mathrm{II})$ system. Clays Clay Miner. 1978, 26, 373-383.

(41) Schwertmann, U.; Thalman, H. The influence of Fe(II), [Si], and $\mathrm{pH}$ on the formation of lepidocrocite during oxidation of aqueous $\mathrm{FeCl}_{2}$ solutions. Clay Miner. 1976, 11, 189-200.

(42) Lewis, D. G.; Schwertmann, U. The influence of $\mathrm{Al}$ on the formation of iron oxide, Part III, Preparation of Al-goethites in M KOH. Clay Miner. 1979, 14, 115-126.

(43) Cornell, R. M.; Giovanoli, R.; Schindler, P. W. Effect of silicate species on the transformation of ferrihydrite into goethite and hematite in alkaline media. Clays Clay Miner. 1987, 35, 21-28.

(44) Jones, A. M.; Collins, R. N.; Rose, J.; Waite, T. D. The effect of silica and natural organic matter on the $\mathrm{Fe}$ (II)-catalysed transformation and reactivity of $\mathrm{Fe}(\mathrm{III})$ minerals. Geochim. Cosmochim. Acta 2009, 73, 4409-4422.

(45) Regenspurg, S.; Brand, A.; Peiffer, S. Formation and stability of schwertmannite in acidic mining lakes. Geochim. Cosmochim. Acta 2004, 68, 1185-1197.

(46) Jonsson, J.; Persson, P.; Sjoberg, S.; Lovgren, L. Schwertmannite precipitated from acid mine drainage: Phase transformation, sulphate release and surface properties. Appl. Geochem. 2005, 20, 179-191.

(47) Schwertmann, U.; Carlson, L. The $\mathrm{pH}$-dependent transformation of schwertmannite to goethite at $25^{\circ} \mathrm{C}$. Clay Miner. 2005, $40,63-66$.

(48) Knorr, K.-H.; Blodau, C. Controls on schwertmannite transformation rates and products. Appl. Geochem. 2007, 22, 20062015.

(49) Catalano, J. G.; Park, C.; Fenter, P.; Zhang, Z. Simultaneous inner- and outer-sphere arsenate adsorption on corundum and hematite. Geochim. Cosmochim. Acta 2008, 72, 1986-2004.

(50) Blanchard, M.; Morin, G.; Lazzeri, M.; Balan, E.; Dabo, I. Firstprinciples simulation of arsenate adsorption on the (1-12) surface of hematite. Geochim. Cosmochim. Acta 2012, 86, 182-195.

(51) Hering, J. G.; Chen, P. Y.; Wilkie, J. A.; Elimelech, M. Arsenic removal from drinking water during coagulation. J. Environ. Eng. 1997, $123,800-807$.

(52) McNeill, L. S.; Edwards, M. Predicting As removal during metal hydroxide precipitation. J. Am. Water Ass. 1997, 89 (1), 75-86.

(53) Robins, R. G.; Singh, P.; Das, R. P. Coprecipitation of arsenic with $\mathrm{Fe}(\mathrm{III})$ and $\mathrm{Al}(\mathrm{III})$ and mixtures of both in chloride system. In Arsenic Metallurgy; TMS Annual Meeting: San Francisco, CA, 2005. 